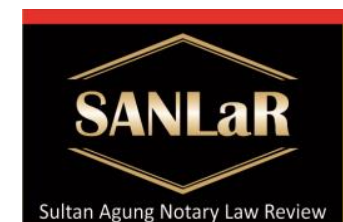

\title{
Role of Notary in Change of Name of Limited Liability Company
}

\author{
Detkri Badhiron *), Umar Ma'ruf **) and Ngadino ***) \\ *) Student Master of Notary Law, Faculty of Law, Universitas Islam Sultan Agung \\ Semarang, Indonesia, E-mail: www.dpnklawfirm.com \\ ${ }^{* *}$ Lecturer Master of Notary Law, Faculty of Law, Universitas Islam Sultan Agung \\ Semarang, Indonesia \\ $\left.{ }^{* * *}\right)$ Lecturer Master of Notary Law, Faculty of Law, Universitas Islam Sultan Agung \\ Semarang, Indonesia
}

\begin{abstract}
This research aims at untuk know and analyze the factors that cause PT. Mega Transformation Indonesia changed to PT. Djaja Bangun Rahardja, besides that this research is also to determine and analyze the role of the Notary in the change of PT. Mega Transformation Indonesia to become PT. Djaja Bangun Rahardja associated with Act No. 40 of 2007 concerning Limited Liability Companies and the latter to identify and analyze the process of barriers and solutions in the process of changing PT. Mega Transformation Indonesia to become PT. Djaja Bangun Rahardja associated with Act No. 40 of 2007 concerning Limited Liability Companies. The approach method in this research isjuridical empirical. Juridical approach (law is seen as norms or das sollen), because in discussing the problem of this research using legal materials (both written and unwritten law or both primary and secondary legal materials). An empirical approach (law as a social, cultural or das sein reality), because in this study primary data obtained from the field were used. So, the empirical juridical approach in this study means that in analyzing the problem it is done by combining legal materials (which are secondary data) with primary data obtained in the field, namely about how the role of the Notary requires empirical research on Notaries who process name changes. names of shareholders and changes in the Board of Directors. The specifications used in this research are descriptiveanalytic, which is intended to provide as accurate a data as possible about a condition or other symptoms, because this research is expected to provide a detailed, systematic and comprehensive description of the role of the notary in processing the name change of a limited liability company. The data required includes dataPrimary data is data obtained from the field, data is obtained from respondents. Respondent is a person or community who provides answers to questions from researchers. Secondary data, namely data obtained from or derived from library materials, secondary data collected in this study include primary legal materials, secondary legal materials and tertiary legal materials.. In discussing the subject matter and analyzing the data that has been obtained, the authors use all the information and data that has been obtained, both primary and secondary data. Then the authors analyzed qualitatively which was then presented descriptively.
\end{abstract}

Keywords: Role; Notary; Limited Liability Company. 


\section{Introduction}

The notary position as a functionary ${ }^{1}$ in society is still very much respected. Notary as an official, is a place for someone to get reliable advice. Everything he writes and determines (constants) is correct, he is a strong document maker in legal proceedings. Every society needs a (figure) whose information can be relied upon, can be trusted whose signature and seal (stamp) provides assurance and strong evidence, an impartial expert and legal advisor who is not flawed (onreukbaar or unimpeachable), who keeps his mouth shut. and make a covenant that can protect it in the days to come. ${ }^{2}$ The notary profession as part of the legal profession is considered a very noble and honorable profession, because the purpose of the legal profession is to uphold law and justice in people's lives. ${ }^{3}$ So that it makes people believe in the notary profession ${ }^{4}$ so that every aspect of life, both social and business, requires a notary's role in relationships between people. Society and business actors in this modern era legal protection in the economic sector between individuals or groups of people is very much needed to ensure security and comfort in doing business. Notary Public. This is one of the legal protections in the business world, both between individuals and groups. This is as described in Article 1 of Act No. 2 of 2014 Amendment to Act No. 30 of 2004 concerning the Position of Notary which provides provisions regarding the definition of a notary, namely: "Notary is a public official who is authorized to make authentic deeds and has other powers as referred to in this Law or based on law. invite others."

The general authority of a notary is regulated in Article 15 paragraph (1), Act No. 30 of 2004 as amended by Act No. 2 of 2014 concerning the Position of Notary Public, the authority is that "Notaries are authorized to make authentic Deeds regarding all actions, agreements, and stipulations required by laws and regulations and/or those interested in being stated in the authentic Deed, guaranteeing the certainty of the making of the Deed, keeping the Deed, providing grosse, copy and quotation of the Deed, all of which as long as the making of the Deed is not assigned or excluded to other officials or other persons determined by law ". 5

That the notary's authority is to create and protect the rights of the community and it cannot be denied that the economic needs of the community continue to develop. An agreement is one of the activities most often made by Notaries in order to protect economic legal actions in society, and it cannot be denied. Today the need for a notary, especially in the business sector, especially Limited Liability Companies as a

\footnotetext{
1 Soerjono, Soekanto and Mamuji Sri, (2001), Penelitian Hukum Normatif suatu tinjauan singkat, Jakarta: Raja Grafindo Persada, p. 43.

2 Tan Thong Kie. Studi Notariat dan Serba-Serbi Praktek Notaris. Jakarta : PT. Ichtiar Baru Van Hoeve. (2007). p. 449.

${ }^{3}$ Yulies Tiena Masriani. Kedudukan Hukum Akta-Akta Notaris Dalam Ekonomi Islam, Serat Acitya-Jurnal Ilmiah. (2013). p. 33

${ }^{4}$ Henny Saida Florida, Peran Notaris Dalam Pembuatan Akta Pendirian dan Akta Perubahan Anggaran Dasar Koperasi. Jurnal Saintech. (2014). p. 61.

${ }^{5}$ Ngadino, Tugas dan Tanggung Jawab Jabatan Notaris di Indonesia, , Semarang: Universitas PGRI Semarang Press. (2019). p. 9
} 
legal entity, is currently a primary need by the global community, because with the interference of a notary, legal protection can be achieved in addition to fulfilling the provisions of the law, in this particular case. Limited Liability Company Law. Thus the presence of an authentic deed which is a legal product born by a notary is a supporter of the creation of the concept of legal certainty which is the basis of justice. Limited Liability Companies as legal entities are supported by the existence of various kinds of laws and regulations which are also an indication of the government's participation or involvement in supporting the world economy as the foundation for the growth and development of a country. Limited Liability Company (PT) is the most preferred form of economic activity business today, because in addition to its limited liability, Limited Liability Companies also make it easy for owners (shareholders) to transfer their company (to everyone) by selling all of their shares in the company. these, as well as other benefits. ${ }^{6}$

Based on what is described above, the authors identify that the change in the name of the company and the composition of shareholders will certainly have an impact on the composition of the board of directors and commissioners even though the replacement process has no problems, but on the legality side it will meet many obstacles and obstacles.

\section{Research Methods}

In a research method is one of the factors for the problems to be discussed, where the research method is the main way that aims to achieve the level of accuracy in the number and type to be achieved. As a scientific work, this research has the aim of expressing the truth systematically methodologically, and consistently in legal research of a scientific activity based on systematics and certain thoughts by analyzing it. ${ }^{7}$

In carrying out this research, the authors use the following methodology:

1. Approach Method

The method used in this paper is juridical empirical. Juridical approach (law is seen as norms or das sollen), because in discussing the problem of this research using legal materials (both written and unwritten law or both primary and secondary legal materials). An empirical approach (law as a social, cultural or das sein reality), because in this study primary data obtained from the field were used. So,

2. Research Specifications

The specifications used in this research are descriptive-analytic, which is intended to provide as accurate a data as possible about a condition or other symptoms. ${ }^{8}$ because this research is expected to provide a detailed, systematic and comprehensive description of the role of the notary in processing the name change of a limited liability company.

\footnotetext{
${ }^{6}$ Yani , Ahmad and Gunawan Widjaja, Perseroan Terbatas. Jakarta: PT. RajaGrafindo Persada, (2003). p. 1.

${ }^{7}$ Dimyati, Khudzaifah and Kelik Wardiyono, Metode Penelitian Hukum, FH UMS. (2004). p. 3.

${ }^{8}$ Soekanto, Soerjono and Sri Mamuji, Penelitian Hukum Normatif suatu tinjauan singkat, Jakarta: Raja Grafindo Persada. (2001). p. 43.
} 
3. Types and Sources of Data

In this study the authors used primary data and secondary data, namely as follows:

a. Primary data is data obtained from the field, data is obtained from respondents. Respondent is a person or community who provides answers to questions from researchers.

b. Secondary data, namely data obtained from or derived from library materials, secondary data collected in this study include primary legal materials, secondary legal materials and tertiary legal materials.

1. Primary Legal Materials, are legal materials in the form of legal norms which have binding characteristics. In this research used, among others:

- 1945 Constitution

- Code of Civil law

- Act No. 2 of 2014 concerning Amendments to Act No. 30 of 2004 concerning the Position of Notary Public.

- Act No. 40 of 2007 concerning Limited Liability Companies

- Regulation of the Minister of Law and Human Rights of the Republic of Indonesia Number: M-01-HT.01-10 of 2007 concerning Procedures for Application for Legal Entity Ratification and Approval of Amendments to Articles of Association, Submission of Notification of Articles of Association and Amendments to Company Data

2. Secondary Legal Material is legal material that is not in the form of legal norms, but in the form of expert opinion, this material is obtained from literature or law books, magazines, newspapers, internet, undergraduate papers in the form of a thesis, thesis or dissertation.

3. Tertiary Legal Materials are materials that provide instructions or explanations for primary and secondary legal materials, in this study the Big Indonesian Dictionary, Legal Dictionary, and Encyclopedia.

4. Data collection technique

In this study the authors used the following data collection techniques:

1. Interview (interview)

Interviewing is a way to obtain information by asking directly to the interviewee, and is a process of interaction and communication. ${ }^{9}$ This interview was conducted with the aim of obtaining data or information on people who are considered to know and it is possible to obtain data that is useful and can be justified for the truth. In this study, the authors conducted interviews at the Notary Office in Yogyakarta.

2. Literature review

This method is done by doing a series such as reading, analyzing, taking notes, and making reviews of library materials that are related to the problems to be studied.

\footnotetext{
${ }^{9}$ Ronny Hanitijo Soemitro. Metode Penulisan Hukum dan Jurimetri. Semarang : Ghalia Indonesia, (1998). p. 57.
} 


\section{Document Study}

Document study is a resource used to complement research, in the form of written sources, pictures (photos), and monumental works, all of which provide information for the research process.

5. Data analysis

In discussing the subject matter and analyzing the data that has been obtained, the authors use all the information and data that has been obtained, both primary and secondary data. Then the authors analyzed qualitatively which was then presented descriptively.

\section{Results and Discussion}

3.1 The role, authority and obligations of a Notary in the mechanism of making the incorporation deed of a Limited Liability Company.

Notary who carries out the duties of the State, who carries out his position to carry out part of the activities of the State's duties in the field of civil law and the authority to make authentic deeds requested by the parties before the Notary ${ }^{10}$ Article 1871 of the Civil Code, which reads "An authentic deed, however, does not provide perfect evidence of what is contained in it as a mere narrative other than what is said is a direct relationship with the subject matter of the deed. In carrying out his/her position, the notary is guided by the statutory provisions in the position of a notary who is attached to two positions as a state official who has duties and functions other than being an authentic deed maker and as a land deed maker official. The provisions governing the duties and functions as land deed-making officials are regulated in Act No. 30 of 2004 in conjunction with Act No. 2 of 2014 concerning the Position of Notary Public, while the provisions regarding the duties and functions of making land deeds are regulated in PP. 37 of 1998 regarding land deed maker officials (PPAT).

Regarding the position of a notary, it has the duty to provide legal certainty services in the form of making authentic deeds and making land deeds in its 2 (two) main functions, namely the first notaries have the responsibility of legal certainty to the community for every ratification of legal binding. both notaries have the authority given by law as state officials to provide legal reinforcement for legal binding. Which ultimately provides peace and security to the community. The responsibility of a notary can be described theoretically, namely: etymologically (grammatically) responsibility comes from the English language, namely "Responsibility" which means responsibility, responsibility or responsibility. Answer coverage means the obligation to provide an answer which is a calculation of all the things that have happened and an obligation to provide recovery for any losses that may arise. ${ }^{11}$

The notary is in the process of asking for syarat to change the name of PT:

a. Changing the name of a PT is a form of amendment to the articles of association, therefore it must go through the mechanism of the General Meeting of Shareholders ("GMS").

\footnotetext{
${ }^{10}$ Habib Adji, Sekilas Dunia Notaris \& PPAT Indonesia (Kumpulan Tulisan). Mandar Maju. (2009). p.16

${ }^{11}$ F. Sugeng Istanto, Hukum Internasional. Jogjakarta: UAY Press ( 1994). p. 77.
} 
b. The GMS to amend the articles of association can be held if at the meeting at least $2 / 3$ (two thirds) of the total shares with voting rights are present or represented in the GMS and the decision is valid if it is approved at least $2 / 3$ (two thirds) of the total. the votes cast, unless the articles of association determine the quorum of attendance and/or provisions concerning the decision making of a larger GMS.

c. Amendments to the articles of association in the form of a change in the name of the company must obtain the approval of the Minister of Law and Human Rights. and published or stated in a notary deed in Indonesian

d. Applications for approval of amendments to articles of association are submitted to the Minister, no later than 30 days from the date of the notarial deed containing the amendments to the articles of association. After the 30 day deadline, applications for approval of amendments to articles of association cannot be submitted or submitted to the Minister.

In the process of changing PT. Mega Transformation Indonesia has carried out a GMS process for the release of shares previously with a composition of 7 shareholders of the same to only 2 shareholders and 1 majority shareholder. The share sale process has been paid for by the surviving shareholders and is set forth in an official report and share sale and purchase receipt. Because one of the majority shareholders then intends to change the name of the company to PT. Djaya Bangun Rahardja.

3.2 Obstacles and Solutions Notaries in drawing up the deed of establishment of the Limited Liability Company have carried out the authorities and obligations as stipulated in the Law on Notary Position.

As long as PT. Mega Transformation Indonesia was established and has never had any projects or jobs. The spirit of establishing this company is to work together both private and government, but due to the busyness of each shareholder so that up to the 4th (fourth) year this company was established there was no progress and the Board of Directors was only concerned with taking care of taxes which annually became company obligations. Some of us have tried projects for the Government, BUMN and private sector experiencing problems, both operational and internal to the company itself so that on May 10, 2019 a General Meeting of Shareholders (GMS) was held to sell shares to one of the Directors who did not own shares because he had a project. in several cities in Indonesia, there is a discourse that all of them will sell shares to one of the Directors. The next process was followed by a meeting with most of the shareholders present, so that $80 \%$ of the shareholders gathered, then a GMS Minutes were made containing the sale and release of shares, then continued with the making of an official report on the sale and purchase of shares, the negotiation process that took place was that all shareholders requested payment in advance while the buyer will pay after the Notary Deed and all the burden of the Notary is on the buyer's side. By making the minutes as follows: 


\section{MEETING AGENDA :}

Change of Deed of PT. Mega Transformation Indonesia No. 11 dated 9 April 2016, Notary Bintari Dyah Ramadhani SH, M.Kn - Bantul in accordance with the Decree of the Minister of Law and Human Rights Number AHU-0019348.AH.01.01.Tahun 20016 concerning the Establishment of the Legal Entity of PT Mega Transformasi Indonesia.

Has attended this meeting:

1. Bima Heri Nugraha, who in this Meeting acted as the President Director of PT. Mega Transformasi Indonesia as well as the holder of 2 2,000,000 shares (two million rupiah);

2. Detkri Badhiron, who in this Meeting acted as the President Director of PT. Mega Transformasi Indonesia as well as the holder of $22,000,000$ shares (two million rupiah);

3. Mohamad Novweni, who in this Meeting acted as President Commissioner of PT. Mega Transformasi Indonesia as well as the holder of 2 2,000,000 shares (two million rupiah);

4. Heribertus Apriadi, who in this Meeting acted as Commissioner of PT. Mega Transformasi Indonesia as well as the holder of $22,000,000$ shares (two million rupiah);

5. Tengku Wahyudi Sapta Putra, who in this Meeting acted as Commissioner of PT. Mega Transformasi Indonesia as well as holding 2 2,000,000 (two million rupiah) shares;

6. Aris Sustiyono, in this Meeting acting as the Director of PT. Mega Transformasi Indonesia;

Meeting results :

The meeting was attended by $80 \%$ of the shareholders of PT. Mega Transformasi Indonesia along with other invitations with the following results:

1. This GMS was held at the request of Aris Sustiyono as Director of PT Mega Transformasi Indonesia because there will be investors or personalities to buy shares of the Company so they can be used for work. 
2. Whereas from the beginning the shareholder named Ricky Novrico was never active in the creation of the Company so that the share transfer mechanism would be acquired according to the applicable provisions while Tengku Hermansyah's shares would be handed over by Tengku Wahyudi SP because he was the sibling of the person concerned.

3. That for the sake of the smooth sale of shares and the life of the company, the shareholders agreed to amend the Deed of PT. Mega Transformation Indonesia No. 11 dated 9 April 2016, Notary Bintari Dyah Ramadhani SH, M.Kn - Bantul in accordance with the Decree of the Minister of Law and Human Rights Number AHU0019348.AH.01.01.Tahun 20016 concerning the Establishment of the Legal Entity of PT Mega Transformasi Indonesia.

The meeting authorizes:

1. Bima Heri Nugraha

2. Detkri Badhiron

Either jointly or individually with the right to transfer this power to another person (substitution) either partially or completely to compose the Minutes of the Meeting into a notary deed and notify the amended Articles of Association of the Company to the competent agency and register with the Ministry Law and Human Rights, Ministry of Trade and Ministry of Forestry and Environment at the domicile of the Company, for this purpose the power of attorney has the right to appear and provide information, make orders and sign deeds/documents needed and then take all actions which is considered good and useful to solve the above.

Because there are no other matters that need to be discussed in this Meeting, all shareholders will jointly close this Meeting at 18.00 West Indonesian Time.

Shareholders

Bima Heri Nugraha

Detkri Badhiron

Mohamad Novweni

Heribertus Apriadi

Tengku Wahyudi Sapta Putra 
In the end, everyone agreed on this, then an official report was made on the following day, with an agreement to make a draft minute of sale and purchase and the composition of the new shareholders. The obstacle that occurred after the GMS was that there were shareholders who were not present outside the city and could not be contacted and after in consultation with the Notary concerned must sign an official report and attach a NPWP and KTP, this is what makes the problem that the sales process of PT. Mega Transformasi Indonesia has not been completed to date. Because what is required according to statutory provisions is not fulfilled.

\section{Closing}

The process of changing a company is not as easy as making it because it must be in accordance with applicable laws and regulations, not to mention the difference in desire among shareholders which results in obstacles in the release of shares, The author's suggestion that if you are going to make changes, the Company must prepare all the requirements in accordance with the applicable laws and regulations.

\section{References}

Journals:

Henny Saida Florida, Peran Notaris Dalam Pembuatan Akta Pendirian dan Akta Perubahan Anggaran Dasar Koperasi. Jurnal Saintech.

Books:

[1] Soerjono, Soekanto and Mamuji Sri, (2001), Penelitian Hukum Normatif suatu tinjauan singkat, Jakarta: Raja Grafindo Persada.

[2] Tan Thong Kie. (2007). Studi Notariat dan Serba-Serbi Praktek Notaris. Jakarta : PT. Ichtiar Baru Van Hoeve.

[3] Yulies Tiena Masriani. (2013). Kedudukan Hukum Akta-Akta Notaris Dalam Ekonomi Islam, Serat Acitya-Jurnal IImiah.

[4] Ngadino. (2019). Tugas dan Tanggung Jawab Jabatan Notaris di Indonesia, Semarang: Universitas PGRI Semarang Press.

[5] Yani, Ahmad and Gunawan Widjaja, Perseroan Terbatas. Jakarta: PT. RajaGrafindo Persada, (2003).

[6] Dimyati. (2004). Khudzaifah and Kelik Wardiyono, Metode Penelitian Hukum, FH UMS.

[7] Ronny Hanitijo Soemitro. (1998). Metode Penulisan Hukum dan Jurimetri. Semarang : Ghalia Indonesia

[8] Habib Adji. (2009). Sekilas Dunia Notaris \& PPAT Indonesia (Kumpulan Tulisan). Mandar Maju.

[9] F. Sugeng Istanto. (1994). Hukum Internasional. Jogjakarta: UAY Press 